\title{
Literature Review: Factors Causing Hearing Loss Due to Noise in Industrial Workers
}

\author{
Literatur Review: Faktor Penyebab Gangguan Pendengaran Akibat Kebisingan \\ pada Pekerja Industri
}

\author{
Amalia Layina Ulfa, Lilis Sulistyorini \\ Department of Environmental Health, Faculty of Public Health Universitas Airlangga \\ Campus C Mulyorejo, Surabaya, East Java 60115 Indonesia
}

\begin{abstract}
Introduction: Industry is a place where many individuals work. In the industrial field, one can do work by utilizing. However, high-tech applications can cause noise in industrial areas. The discomfort of this sound may indirectly pose a risk of health problems, including hearing loss. Methods: The method used in this study wasa literature review study with an in-depth review of the articles through an electronic article data base with the keywords noise, hearing loss, and industrial workers. Then, a screening was carried out based on articles that have been published in a period of five years, and the sorting of articles was conducted according to the inclusion criteria, namely primary data research with cross sectional design, not descriptive research. Results: The journal research phase resulted in up to 101 papers, with 51 papers screened under pre-determined conditions. Then, sorting based on inclusion criteria resulted in 28 items. Finally, as many as 11 relevant articles and the full text were obtained as a result. Based on the review of the article, it is known that hearing loss that occurs among industrial workers is influenced by several problems in the industry such as the absence of noise measurements, the absence of ear health checks for workers, and the unavailability of ear protection equipment. Conclusion: Based on the review of the articles, it is known that hearing loss is caused by high noise levels. Besides, there are other factors that can affect hearing loss in workers such as age, working period, use of ear protection equipment, and a history of ear disease.
\end{abstract}

Keywords: hearing loss, industry, literature review, noise

\begin{abstract}
ABSTRAK
Pendahuluan: Industri merupakan tempat yang difungsikan untuk beberapa orang melakukan pekerjaan. Dalam bidang industri seseorang dapat melakukan pekerjaan dengan memanfaatkan teknologi. Penggunaan teknologi berbasis tinggi dapat menimbulkan kebisingan di area industri. Ketidaknyamanan dari adanya kebisingan ini yang secara tidak langsung dapat memberikan risiko terhadap terjadinya gangguan kesehatan terutama pada pendengaran. Metode: Metode yang digunakan adalah studi literature review dengan telaah artikel secara mendalam melalui data base artikel elektronik dengan kata kunci kebisingan, gangguan pendengaran, dan pekerja industri. Kemudian dilakukan screening berdasarkan artikel yang sudah dipublikasi dalam kurun waktu lima tahun dan pemilahan artikel sesuai dengan kriteria inklusi yaitu penelitian data primer berdesain cross sectional bukan penelitian deskriptif. Hasil: Tahap pencarian jurnal didapatkan sebanyak 101 artikel, dilakukan screening yang sesuai dengan syarat yang telah ditentukan didapatkan sebanyak 51 artikel. Kemudian dilakukan pemilahan yang sesuai dengan kriteria inklusi didapatkan sebanyak 28 artikel. Ditemukan sebanyak 11 artikel yang relevan dan full text yang sesuai. Berdasarkan telaah artikel diketahui gangguan pendengaran yang terjadi pada pekerja industri dipengaruhi oleh beberapa permasalahan di industry seperti belum melakukan adanya pengukuran kebisingan, tidak adanya pemeriksaan kesehatan telinga bagi pekerja, dan belum tersedianya alat pelindung telinga (APT). Simpulan: Berdasarkan review artikel diketahui bahwa gangguan pendengaran disebabkan oleh tingkat kebisingan yang tinggi, selain itu terdapat faktor lain yang dapat mempengaruhi gangguan pendengaran pada pekerja seperti umur, masa kerja, penggunaan alat pelindung telinga (APT), dan riwayat penyakit telinga.
\end{abstract}

Kata kunci: gangguan pendengaran, industri, kebisingan, literature review

Corresponding Author:

Amalia Layina Ulfa

Email: amalia.layina.ulfa-2016@fkm.unair.ac.id

Telephone: +6282244598456

\section{INTRODUCTION}

Globalization provides rapid changes in terms of industry in the macrocosm. Currently competition in the industrial field between countries in the world 
is experiencing a very important change. This change can be realized through the production of technology used for the development of increasingly sophisticated industries. There is a shift from the technology used manually to high technology, which is currently widely discussed because it has a significant impact on health (Mulyati, Jubaidi and Ali, 2015).

The industry, which is currently increasing, is making a great contribution to help the country's economy. More and more industries that are developing in an area are likely to have problems. The problem in this case can be in the form of the work environment that is not given much attention. In fact, the work environment can cause hazardous conditions for workers such as the occurrence of workplace accidents that affect the health of workers (Hidayat, Purnawati and Dahliyani, 2019). Industrial workers are certainly familiar with machines or production equipment that are grounded on high technology that gives noise effects every day. This noise is the initial door to the process leading to health problems for workers.

Noise in the work environment is a physical, environmental factor that has a health impact on workers. The sound that travels through the air coming from the use of production machines in industrial environments with high intensity can interfere with the comfort of workers. Noise pollution arising from the industrial sector is what gives health effects in the strain of hearing loss (Ramadhani and Firdausiana, 2020). The risk of noise in this industrial sector has become a popular public debate. It is known that there are 600 million workers in the industrial sectors such as mining, oil, and other industrial sectors throughout the world who are being exposed to noise (Buksh et al., 2018).

Regularization of the Minister of Manpower of the Republic of Indonesia Number 5 Year 2018 Concerning Occupational Safety and Health states that noise that is allowed to be exposed to humans for 8 hours of work is $85 \mathrm{dBA}$ in accordance with the noise threshold value. Noise threshold is a value that is tolerated and accepted by workers during work and circumstances where workers do not feel there are complaints or hearing-related disorders. The industrial sector creates noise for not only workers, but also the community or residents who also live in industrial areas and accept any inconvenience caused by noise during the production process.
The need to reduce noise in the industrial sector can help reduce noise not only for workers but also for ordinary people who reside around the industry. Noise due to the industrial sector is also felt by the public such as the issue of subjective complaints of hearing impairment. On average, the affected community is women because they often stay at home, so they receive high noise intensity more often (Busyairi, Tosungku and Patibong, 2014).

Hearing loss due to noise usually does not occur quickly, but it takes a long exposure to the high noise intensity even until decades. When this happens, someone who has hearing loss will experience a hearing disability that is not curable (irreversible). In fact, the occurrence of hearing loss in workers who work in the industrial sector is not simply caused by noise, but there are other factors that can also cause a person suffering from hearing loss including the behaviour of workers in the industrial sector who are less compliant with the use of personal protective equipment, the habit of using headsets, and consumption of drugs. Hearing loss can be identified by taking medical examinations using audiometry to see the hearing threshold value (Retnaningsih, 2016).

Noise in the work environment was also found in one of the power generation industries, namely PT. PLN (Persero) East Kalimantan Region Mahakam Sector PLTD X Samarinda. During the operational process of supplying electricity at the workplace, there were several machines that caused noise. When measured using a sound level meter with three measurement points, it was found that the noise intensity in the work environment of the power plant had an average of $98.6 \mathrm{dBA}-100.4 \mathrm{dBA}$. Workers felt some complaints while working such as, among others, a feeling of discomfort during work, but after the interview the workers' complaints were felt to be relatively lessened (Busyairi, Tosungku and Patibong, 2014).

Noise in the industry was also found in the saga and abrasive process carried out by Tongas in the forest industry. It is known that the sugar and sanding process in the forest industry produces noise which also comes from the waves of the sanding machine. Based on the results of the study there were some workers who felt that they had hearing complaints because the intensity of the noise coming from the sanding machine exceeded the threshold value. The noise level generated from the process was $92.538 \mathrm{dBA}$ while for the hearing threshold of workers in the sugar process section was 36.209 
$\mathrm{dB}$ and the welding part is $36.347 \mathrm{~dB}$. Thus, it can be seen that many workers have experienced an increase in the hearing threshold while doing work in the wood industry (Kusmindari, 2008).

The number of industrial workers who experience hearing loss due to noise has triggers some researchers to conduct research on such topic such as that studies conducted (Mulyati, Jubaidi and Ali, 2015; Marisdayana, Suhartono and Nurjazuli, 2016; and Chusna, Huboyo and Andarani, 2017). Based on this, the researchers are encouraged to conduct a literature review study to look for similarities and conflicts from each study related to the factors underlying the occurrence of hearing loss in industrial workers.

\section{METHODS}

The method used in this research was the literature review with no ethics review. The journals used were obtained from a database of electronic journals such as Google Scholar and Research Gate. The keywords used in the search were noise and factors that cause hearing loss (Google Scholar) and "noise" and "hearing loss" (Research Gate). Sorting was done by screening based on the journals that had been issued within a period of five years. After screening the journals were chosen in accordance with the inclusion criteria, namely research conducted primarily with cross sectional design and not descriptive research.

The search results through Google Scholar and Research Gate were as many as 101 subjects. Of 101 articles, screening was conducted in accordance with the provisions made, so that a total of 51 articles were selected. Afterwards, the 51 articles that met the screening were analyzed in accordance with the inclusion criteria for selection, and as many as 28 articles (full text) were obtained. The concluding stage in the selection of articles was to determine the independent and dependent variables that were been determined by the researchers, and 11 relevant articles and "full text" were obtained.

The field design of the eleven articles used a cross section in which the researchers conducted research at the same time. In selecting respondents to serve as research studies, each article employed different techniques. In the journal of Suryani, Mulyadi and Afandi (2015); Fachrul, Moerdjoko and Verogetta (2016); Royan, Dermawan and Wiediartini (2015); Marisdayana, Suhartono and Nurjazuli (2016) the researchers used the total population in conducting research on the relationship of noise intensity with hearing loss. Research

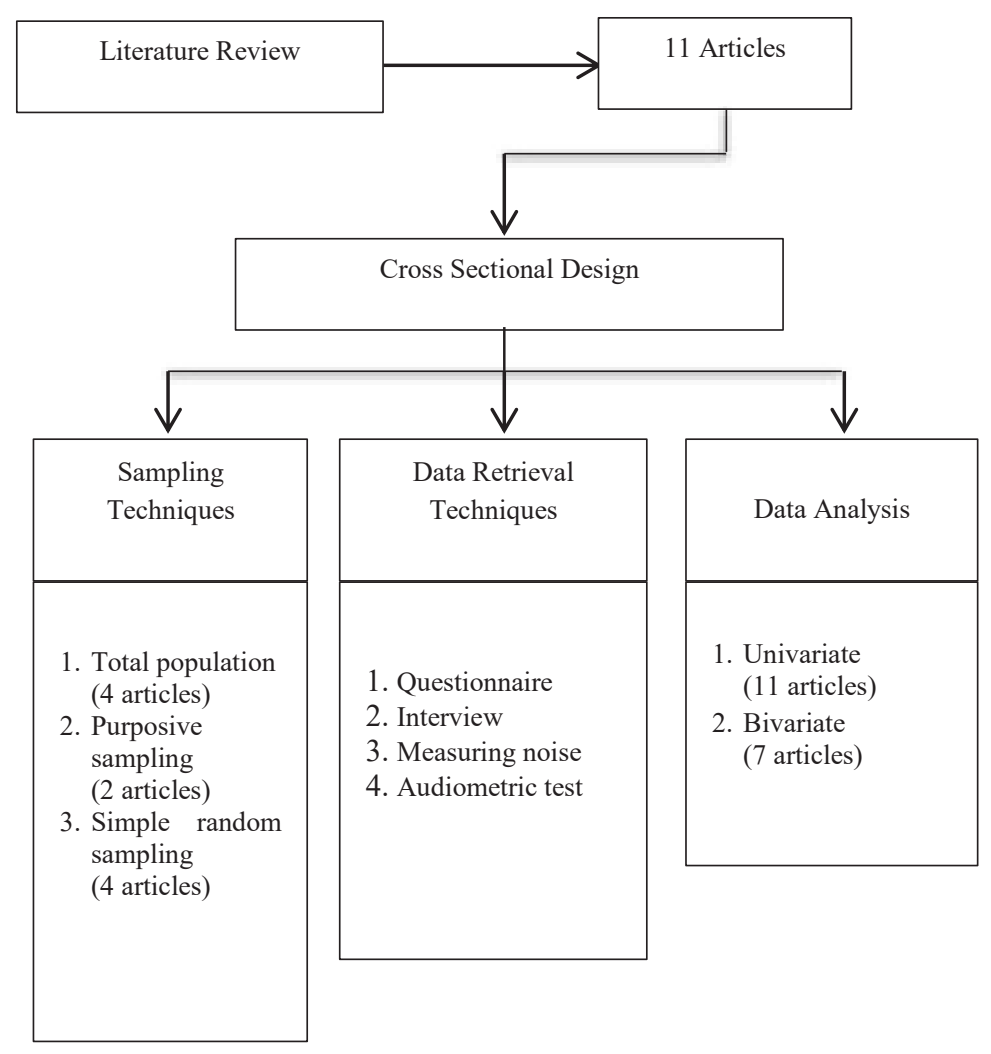

Figure 1. Research Step of the Articles 
Mulyati, Jubaidi and Ali (2015); Chusna, Huboyo and Andarani (2017) used purposive sampling techniques, which are sampling techniques that adapt to predetermined criteria. Meanwhile, research by Ramadhani and Firdausiana (2020); Sincihu et al. (2019); Jayanti, Suwondo and Marlina (2016); Minggarsari and Sahuri (2019) used simple random sampling, which was done to determine respondents randomly.

Overall, the research was directed using a questionnaire through interviews with respondents. Measurements of environmental data were also conducted by researchers by measuring noise using a sound level meter and carrying out hearing health checks on workers using audiometric tests. Eleven journals also presented univariate analysis, but only seven journals found sufficient analysis so that only a few factors could be involved in the occurrence of hearing loss.

\section{RESULTS}

Disturbance is a physical, environmental factor in the workplace that can cause occupational diseases and work-related accidents (Mulyati, Jubaidi and Ali, 2015). Based on these problems, there were as many as 802 workers with workrelated accidents and occupational diseases with the rate of occurrence has kept increasing increased during the three years since 2012. This is due to the high intensity of machine noise in the workplace environment. Research on the issue of noise and its

\section{Problems in the Articles}

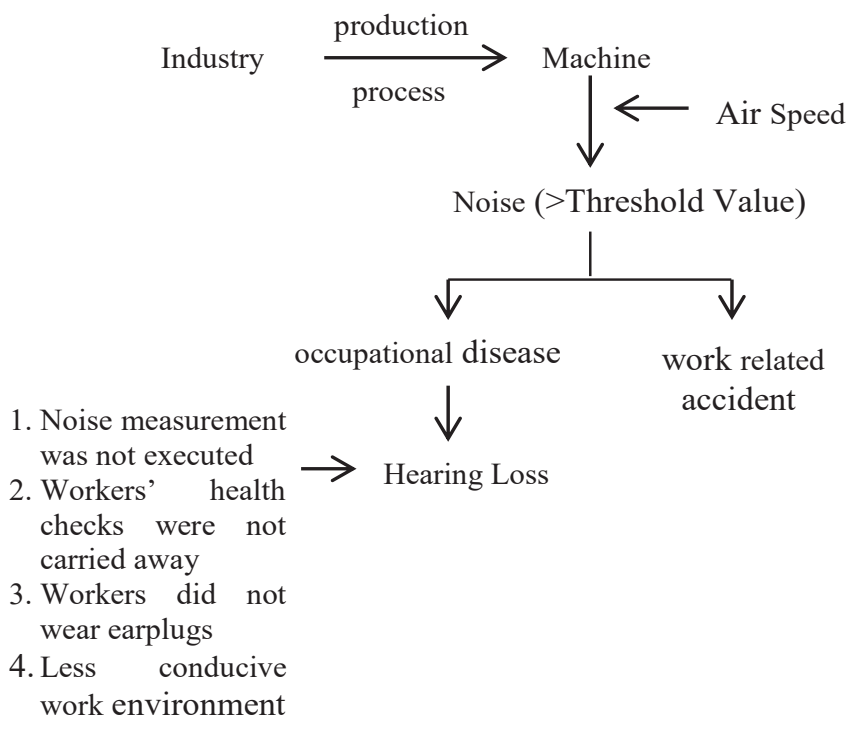

Figure 2. Flow Chart of the Problems in the Articles relation to hearing loss in eight journals show some similarities and differences. About eight journals used for the literature review in this study focus on the topic of noise and show that the disturbances are caused by the high noise intensity in the work environment exposed to workers.

Machines and equipment utilized during the production process in the company on average produce noise either low or high noise levels. As in research conducted by Chusna, Huboyo and Andarani (2017) and Umyati, Yadi and Anton (2015), it is stated that production machines produce high noise and the machines operate for 24 hours, while seven other journals mentioned that noise also comes from the production process machines that operate for 8 hours a daylight. Unfavorable work environment conditions, as stated by Marisdayana, Suhartono and Nurjazuli (2016), can also generate high noise due to company buildings that do not have walls at the back so that sounds that occur outside the production process due to machines can be heard, which will later increase the intensity of noise in the work environment.

The actual work environment has an influence on the occurrence of health problems for workers. A safe work environment will have a positive impact on workers. For example, there is a work environment where the building is not sturdy or there is some space where the edifice is not strong. This condition will increase the risk for workers when doing their work. In addition to the workforce being at risk from adverse health impacts at work such as noise, labor also has the risk of accidents in the workplace. If the work environment does not have a sturdy building or the building is not perfect, it will cause accidents for workers such as workers falling on a collapsed wall, or even other accidents. Moreover, it should be noted that the health and safety of workers are something that must be guaranteed by the company.

Hearing loss that occurs in workers in the industry is influenced by several factors other than noise in the workplace environment. These components include, among others, the fact that companies have never measured noise intensity and conducted health checks for workers, as stated in research by Jayanti, Suwondo and Marlina (2016); Suryani, Mulyadi and Afandi (2015). This occurs because some companies feel that noise is still within reasonable limits, so they do not provide personal protective equipment such as earplugs. The personal protective equipment provided by the factory is sometimes not used by workers on the 
Table 1. Literature Review Tabel

\begin{tabular}{|c|c|c|c|c|c|c|}
\hline Researcher & Title & $\begin{array}{l}\mathrm{R} \text { e s e a } \mathrm{r} \mathbf{c h} \\
\text { Background }\end{array}$ & $\begin{array}{l}\text { Respondent } \\
\text { Retrieval }\end{array}$ & Research Variable & $\underset{\text { Step }}{R \text { e s e a r c h }}$ & Result \\
\hline $\begin{array}{l}\text { Mulyati, } \\
\text { Jubaidi and } \\
\text { Ali (2015) }\end{array}$ & $\begin{array}{l}\text { Factors Related } \\
\text { to Hearing } \\
\text { Impairment on } \\
\text { Manpower of PT } \\
\text { BNT Bengkulu } \\
\text { Tengah }\end{array}$ & $\begin{array}{l}\text { High rates of } \\
\text { occupational } \\
\text { disease and } \\
\text { work accidents } \\
\text { due to } \\
\text { interference }\end{array}$ & $\begin{array}{l}\text { The } \\
\text { respondents } \\
\text { in this study } \\
\text { were as many } \\
\text { as } 56 \text { people } \\
\text { taken through } \\
\text { purposive } \\
\text { sampling }\end{array}$ & $\begin{array}{l}\text { Independent Variables } \\
\text { - Individual } \\
\text { characteristics (age, } \\
\text { working period, } \\
\text { knowledge, use of ear } \\
\text { protection equipment) } \\
\text { - Noise } \\
\text { Dependent Variable } \\
\text {-Hearing Loss }\end{array}$ & $\begin{array}{l}\text { Primary } \\
\text { data (noise } \\
\text { measurement } \\
\text { audiometry } \\
\text { test) }\end{array}$ & $\begin{array}{l}\text { Hearing loss } \\
\text { is affected } \\
\text { by working } \\
\text { period }\end{array}$ \\
\hline $\begin{array}{l}\text { Royan, } \\
\text { Dermawan } \\
\text { and } \\
\text { Wiediartini } \\
(2015)\end{array}$ & $\begin{array}{l}\text { Analytical Study } \\
\text { on The Issue of } \\
\text { Noise and Worker } \\
\text { Characteristics } \\
\text { on Workers' } \\
\text { Hearing Loss in } \\
\text { the Production } \\
\text { Section }\end{array}$ & $\begin{array}{l}\text { The machines } \\
\text { in the } \\
\text { production } \\
\text { process } \\
\text { produce } \\
\text { continuous } \\
\text { noise }\end{array}$ & $\begin{array}{l}\text { The } \\
\text { respondents in } \\
\text { this study were } \\
\text { as many as } 33 \\
\text { people taken } \\
\text { from the total } \\
\text { population }\end{array}$ & $\begin{array}{l}\text { Independent Variables } \\
\text { - Individual } \\
\text { characteristics (age, } \\
\text { working period, use of } \\
\text { ear protection equipment, } \\
\text { headset exposure) } \\
\text { - Noise } \\
\text { Dependent Variable } \\
\text { - Hearing Loss }\end{array}$ & $\begin{array}{l}\text { Primary } \\
\text { data (noise } \\
\text { measurement) } \\
\text { Secondary } \\
\text { data } \\
\text { (audiometry } \\
\text { test) }\end{array}$ & $\begin{array}{l}\text { Noise and } \\
\text { individual } \\
\text { characteristics } \\
\text { affect hearing } \\
\text { loss in the } \\
\text { right auricle }\end{array}$ \\
\hline $\begin{array}{l}\text { Umyati, Yadi } \\
\text { and Anton } \\
(2015)\end{array}$ & $\begin{array}{l}\text { Influence of } \\
\text { Noise Level } \\
\text { Against } \\
\text { Hearing Loss in } \\
\text { Employees of PT. } \\
\text { Citratama Persada } \\
\text { Raya, Blasting } \\
\text { Painting }\end{array}$ & $\begin{array}{l}\text { Noise } \\
\text { measurement } \\
\text { with a figure } \\
\text { that exceeded } \\
\text { the threshold } \\
\text { value in the } \\
\text { blasting area }\end{array}$ & $\begin{array}{l}\text { The } \\
\text { respondents in } \\
\text { this study were } \\
\text { as many as } 11 \\
\text { people }\end{array}$ & $\begin{array}{l}\text { Independent Variables } \\
\text { - Individual } \\
\text { characteristics (age, } \\
\text { working period, use of ear } \\
\text { protection equipment) } \\
\text { - Noise } \\
\text { Dependent Variable } \\
\text { - Hearing Loss }\end{array}$ & $\begin{array}{l}\text { Primary } \\
\text { data (noise } \\
\text { measurement) } \\
\text { Secondary } \\
\text { data } \\
\text { (audiometry } \\
\text { test) }\end{array}$ & $\begin{array}{l}\text { Noise and } \\
\text { working life } \\
\text { are linked with } \\
\text { hearing loss }\end{array}$ \\
\hline $\begin{array}{l}\text { Suryani, } \\
\text { Mulyadi and } \\
\text { Afandi (2015) }\end{array}$ & $\begin{array}{l}\text { Analysis of } \\
\text { Sensorineural } \\
\text { Type of Hearing } \\
\text { Loss on Workers } \\
\text { Due to Noise } \\
\text { in the Wood } \\
\text { Furniture Industry } \\
\text { in Pekanbaru City }\end{array}$ & $\begin{array}{l}\text { In a research } \\
\text { site, there was } \\
\text { a noise hazard } \\
\text { coming from } \\
\text { the production } \\
\text { machine }\end{array}$ & $\begin{array}{l}\text { The } \\
\text { respondents in } \\
\text { this study were } \\
\text { as many as } 27 \\
\text { people, taken } \\
\text { from total } \\
\text { population }\end{array}$ & $\begin{array}{l}\text { Independent Variables } \\
\text { - Individual } \\
\text { characteristics (age, } \\
\text { working period, use of } \\
\text { ear protection equipment, } \\
\text { gender, education) } \\
\text { - Noise } \\
\text { Dependent Variable } \\
\text { - Hearing Loss }\end{array}$ & $\begin{array}{l}\text { Primary } \\
\text { data (noise } \\
\text { measurement) } \\
\text { Secondary } \\
\text { data } \\
\text { (audiometry } \\
\text { test) }\end{array}$ & $\begin{array}{l}\text { Working life } \\
\text { and age have } \\
\text { a relationship } \\
\text { with } \\
\text { sensorineural } \\
\text { hearing loss }\end{array}$ \\
\hline $\begin{array}{l}\text { Fachrul, } \\
\text { Moerdjoko } \\
\text { and Verogetta } \\
\text { (2016) }\end{array}$ & $\begin{array}{l}\text { Noise Level } \\
\text { Measurement on } \\
\text { Workers' Health } \\
\text { Disorders in the } \\
\text { IB Factory PT } \\
\text { Pupuk Sriwidjaja } \\
\text { Palembang }\end{array}$ & $\begin{array}{l}\text { Compressor } \\
\text { machines in } \\
\text { the production } \\
\text { process that } \\
\text { produced } \\
\text { noise }\end{array}$ & $\begin{array}{l}\text { The } \\
\text { respondents } \\
\text { in this study } \\
\text { were as } \\
\text { many as } 116 \\
\text { people, taken } \\
\text { from total } \\
\text { population }\end{array}$ & $\begin{array}{l}\text { Independent Variables } \\
\text { - Individual } \\
\text { characteristics (age, } \\
\text { working period, workers } \\
\text { in ammonia and urea } \\
\text { areas) } \\
\text { - Noise } \\
\text { Dependent Variable } \\
\text { - Hearing Loss }\end{array}$ & $\begin{array}{l}\text { Primary } \\
\text { data (noise } \\
\text { measurement) } \\
\text { Secondary } \\
\text { data } \\
\text { (audiometry } \\
\text { test) }\end{array}$ & $\begin{array}{l}\text { Workers in the } \\
\text { area were at } \\
\text { bigger risk of } \\
\text { hearing loss }\end{array}$ \\
\hline $\begin{array}{l}\text { Jayanti, } \\
\text { Suwondo } \\
\text { and Marlina } \\
\text { (2016) }\end{array}$ & $\begin{array}{l}\text { Risk Factor } \\
\text { Analysis of } \\
\text { Sensorineural } \\
\text { Hearing Loss On } \\
\text { Workers at PT. X } \\
\text { Semarang }\end{array}$ & $\begin{array}{l}\text { Noise that } \\
\text { exceeded the } \\
\text { threshold } \\
\text { value and } \\
\text { workers who } \\
\text { were less } \\
\text { obedient in } \\
\text { using PPE }\end{array}$ & $\begin{array}{l}\text { The } \\
\text { respondents } \\
\text { in this study } \\
\text { were as many } \\
\text { as } 66 \text { people, } \\
\text { taken through } \\
\text { simple random } \\
\text { sampling }\end{array}$ & $\begin{array}{l}\text { Independent Variables } \\
\text { - Individual } \\
\text { characteristics (age, } \\
\text { working period, use of } \\
\text { ear protection equipment, } \\
\text { hyper cholesterol, } \\
\text { diabetes, high blood } \\
\text { pressure) } \\
\text { - Noise } \\
\text { Dependent Variable } \\
\text { - Sensorineural hearing } \\
\text { Loss }\end{array}$ & $\begin{array}{l}\text { Primary } \\
\text { data (noise } \\
\text { measurement, } \\
\text { audiometry } \\
\text { test) }\end{array}$ & $\begin{array}{l}\text { Noise } \\
\text { intensity, age, } \\
\text { and history of } \\
\text { hypertension } \\
\text { were risk } \\
\text { factors for } \\
\text { sensorineural } \\
\text { hearing loss }\end{array}$ \\
\hline
\end{tabular}


Continued Table 1.

\begin{tabular}{|c|c|c|c|c|c|c|}
\hline Researcher & Title & $\begin{array}{l}R \underset{\text { Background }}{\text { e }} \text { s e a } \mathbf{r} \text { e } h \\
\text { e }\end{array}$ & $\begin{array}{c}\text { Res p o nd e n t } \\
\text { Retrieval }\end{array}$ & Research Variable & $\underset{\text { Step }}{R \text { e s e a } r \text { c h }}$ & Result \\
\hline $\begin{array}{l}\text { Marisdayana, } \\
\text { Suhartono } \\
\text { and Nurjazuli } \\
(2016)\end{array}$ & $\begin{array}{l}\text { Relationship } \\
\text { between } \\
\text { Intensity of } \\
\text { Noise Exposure } \\
\text { and Hearing } \\
\text { Impairment on } \\
\text { Employees at } \\
\text { PT. X }\end{array}$ & $\begin{array}{l}\text { Inadequate working } \\
\text { environment } \\
\text { conditions resulting } \\
\text { in high interference } \\
\text { length of work, } \\
\text { familial history, } \\
\text { and history of ear } \\
\text { diseases }\end{array}$ & $\begin{array}{l}\text { The respondents } \\
\text { in this study } \\
\text { were as many } \\
\text { as } 101 \text { people, } \\
\text { taken from total } \\
\text { population }\end{array}$ & $\begin{array}{l}\text { Independent } \\
\text { Variables } \\
\text { - Individual } \\
\text { characteristics (age, } \\
\text { working period, } \\
\text { length of work, } \\
\text { familial history, } \\
\text { history of ear } \\
\text { diseases) } \\
\text { - Noise } \\
\text { Dependent Variable } \\
\text { - Hearing Loss }\end{array}$ & $\begin{array}{l}\text { Primary } \\
\text { data (noise } \\
\text { measurement, } \\
\text { audiometry } \\
\text { test) }\end{array}$ & $\begin{array}{l}\text { Length of } \\
\text { work and } \\
\text { history of } \\
\text { ear diseases } \\
\text { put workers } \\
\text { at risk of } \\
\text { hearing loss }\end{array}$ \\
\hline $\begin{array}{l}\text { Chusna, } \\
\text { Huboyo and } \\
\text { Andarani } \\
\text { (2017) }\end{array}$ & $\begin{array}{l}\text { Analysis of } \\
\text { Noise Equipment } \\
\text { Manufacturer to } \\
\text { Hearing Power of } \\
\text { Workers at PT. } \\
\text { Pura Barutama } \\
\text { Unit PM } 569 \\
\text { Holy }\end{array}$ & $\begin{array}{l}\text { Production } \\
\text { processes that } \\
\text { produced noise } \\
\text { exceeding the } \\
\text { threshold value }\end{array}$ & $\begin{array}{l}\text { The respondents } \\
\text { in this study } \\
\text { were as many } \\
\text { as } 45 \text { people, } \\
\text { taken through } \\
\text { purposive } \\
\text { sampling }\end{array}$ & $\begin{array}{l}\text { Independent } \\
\text { Variables } \\
\text { - Individual } \\
\text { characteristics (age, } \\
\text { working period) } \\
\text { - Noise } \\
\text { Dependent Variable } \\
\text { - Hearing Loss }\end{array}$ & $\begin{array}{l}\text { Primary } \\
\text { data (noise } \\
\text { measurement, } \\
\text { audiometry } \\
\text { test) }\end{array}$ & $\begin{array}{l}\text { Noise that } \\
\text { exceeded } \\
\text { threshold } \\
\text { value } \\
\text { might result } \\
\text { in hearing } \\
\text { loss }\end{array}$ \\
\hline $\begin{array}{l}\text { Sincihu et al., } \\
(2019\end{array}$ & $\begin{array}{l}\text { Investigation of } \\
\text { Noise Induced } \\
\text { Hearing Loss } \\
\text { at a Shipyard } \\
\text { Company, } \\
\text { Surabaya }\end{array}$ & $\begin{array}{l}\text { Screening of } \\
\text { workers suffering } \\
\text { from NIHL }\end{array}$ & $\begin{array}{l}\text { The respondents } \\
\text { in this study } \\
\text { were as many as } \\
64 \text { people, taken } \\
\text { through simple } \\
\text { random sampling }\end{array}$ & $\begin{array}{l}\text { Independent } \\
\text { Variables } \\
\text { - Individual } \\
\text { characteristics (age, } \\
\text { smoking habit, } \\
\text { alcohol consumption } \\
\text { habit, headset } \\
\text { wearing habit, ear } \\
\text { protector wearing } \\
\text { habit) } \\
\text { - Noise } \\
\text { Dependent Variable } \\
\text { - Noise Induced } \\
\text { Hearing Loss }\end{array}$ & $\begin{array}{l}\text { Primary } \\
\text { data (noise } \\
\text { measurement, } \\
\text { audiometry } \\
\text { test) }\end{array}$ & $\begin{array}{l}\text { The habit } \\
\text { of not } \\
\text { using PPE } \\
\text { affected the } \\
\text { NIHL }\end{array}$ \\
\hline $\begin{array}{l}\text { Minggarsari } \\
\text { and Sahuri } \\
(2019)\end{array}$ & $\begin{array}{l}\text { Relationship } \\
\text { between Noise } \\
\text { Intensity with } \\
\text { Auditory } \\
\text { Complaints on } \\
\text { Workers in a } \\
\text { Steel Fabrication } \\
\text { Factory in the } \\
\text { Production Unit }\end{array}$ & $\begin{array}{l}\text { Complaints from } \\
\text { workers regarding } \\
\text { symptoms of } \\
\text { hearing loss }\end{array}$ & $\begin{array}{l}\text { The respondents } \\
\text { in this study } \\
\text { were as many } \\
\text { as } 80 \text { people, } \\
\text { taken through } \\
\text { simple random } \\
\text { sampling }\end{array}$ & $\begin{array}{l}\text { Independent Variable } \\
\text { - Noise } \\
\text { Dependent Variable } \\
\text { - Auditory complaints }\end{array}$ & $\begin{array}{l}\text { Primary } \\
\text { data (noise } \\
\text { measurement, } \\
\text { audiotory } \\
\text { complaints) }\end{array}$ & $\begin{array}{l}\text { High noise } \\
\text { levels } \\
\text { could cause } \\
\text { auditory } \\
\text { disturbance } \\
\text { complaints }\end{array}$ \\
\hline $\begin{array}{l}\text { Ramadhani } \\
\text { and } \\
\text { Firdausiana } \\
(2020)\end{array}$ & $\begin{array}{l}\text { Noise and } \\
\text { Hearing Loss } \\
\text { Exposure of } \\
\text { Field Operators } \\
\text { in a Compressor } \\
\text { House Area }\end{array}$ & $\begin{array}{l}\text { Compressor } \\
\text { machines that } \\
\text { produced high } \\
\text { noise and } \\
\text { individual factors } \\
\text { that could hinder } \\
\text { the occurrence of } \\
\text { hearing loss }\end{array}$ & $\begin{array}{l}\text { The respondents } \\
\text { in this study } \\
\text { were as many as } \\
32 \text { people, taken } \\
\text { through simple } \\
\text { random sampling }\end{array}$ & $\begin{array}{l}\text { Independent } \\
\text { Variables } \\
\text { - Individual } \\
\text { characteristics (age, } \\
\text { working period) } \\
\text { - Noise } \\
\text { Dependent Variable } \\
\text { - Hearing Loss }\end{array}$ & $\begin{array}{l}\text { Primary } \\
\text { data (noise } \\
\text { measurement, } \\
\text { audiometry } \\
\text { test) }\end{array}$ & $\begin{array}{l}\text { Noise } \\
\text { intensity } \\
\text { had a } \\
\text { correlation } \\
\text { with right } \\
\text { ear hearing } \\
\text { disturbance }\end{array}$ \\
\hline
\end{tabular}

grounds and they also easily get lost due to their small size. Besides, workers also feel that they have not experienced any complaints of hearing loss. Morever, there is no supervision from the industry in using personal protective equipment. All of this leads to the emergence of occupational diseases such as hearing loss due to disturbance. 


\section{DISCUSSION}

The results of research from eight journals mentioned that hearing loss in workers is caused by several components. The predominant factor causing this is noise in the work environment originating from machinery and other production activities. Other things such as a history of ear disease can also worsen the hearing state of workers. Besides, hearing loss is also influenced by individual characteristics, including age, years of service, noise intensity, use of personal protective equipment, length of work, and individual vulnerability. The neighborhood also affects the hearing loss of a person because a residence that is crowded or close to bodily functions that produce noise, for the example a residence that is on the edge of a railroad, can also cause hearing loss.

Research conducted by Mulyati, Jubaidi and Ali (2015), Royan, Dermawan and Wiediartini (2015), and Minggarsari and Sahuri (2019) stated that hearing loss is affected by the presence of high intensity noise in in the work process. Besides, age, years of service, use of personal protective equipment, and knowledge of workers are factors that affect hearing loss. It is generally known that increasing age can cause a decline in organ function, one of which is hearing. In business with research conducted by Jayanti, Suwondo and Marlina (2016); Suryani, Mulyadi and Afandi (2015), it is stated that the average age of workers with hearing loss is more than 40 years of age. This is because the company hires employees until a predetermined time (according to the employment contract), so many workers have a working period.

Working period is the length of time someone does work in a matter of years. Knowing the years of service can reveal the occurrence of hearing loss because the longer the work period of a person, the higher the exposure to hazards that will affect health conditions. Research conducted by Marisdayana, Suhartono and Nurjazuli (2016); Suryani, Mulyadi and Afandi (2015); Mulyati, and Jubaidi and Ali (2015) stated that long periods of work can cause hearing loss if supported by workers who are less obedient in using personal protective equipment. The role of personal protective equipment is one of the methods that is often ignored by workers because workers feel they do not need personal protective equipment such as earplugs while working. This is in line with research conducted by Sincihu et al. (2019) and Umyati, Yadi and Anton (2015) pointing out the habits of workers who are disobedient in using personal protective equipment such as earplugs occur because workers feel uncomfortable, so they often eliminate earplugs and forget to bring them to work.

The eight journals obtained also have differences in the results of their analysis. Umyati, Yadi and Anton (2015); Royan, Dermawan and Wiediartini (2015); Ramadhani and Firdausiana (2020) that presented data related to hearing loss by mentioning the hearing threshold of the right ear and left ear of workers. The rest of the seven journals only mentioned is the presence of a hearing loss without presenting a hearing threshold value from the audiometric test conducted. Another component that can also affect the occurrence of hearing loss in workers is a history of hypertension, as shown in research conducted at PT. X Semarang. Workers with a history of hypertension are more likely to experience an increase in the hearing threshold due to the effect of high intensity noise.

Based on the results of 11 articles, it is known that research variables that can cause hearing loss include noise level, years of service, age, use of personal protective equipment, history of high blood pressure and a history of ear disease. The relationship between the variables that will be discussed in this case is the research variable that usually causes hearing loss in industrial workers the most. These variables include noise level, years of service, age and use of personal protective equipment.

Noise is a physical factor that will be found in industrial environments because the production process conducted in each industry always produces noise with different levels of noise. Companies that comply with laws and regulations will carry out environmental measurements at their companies on a regular basis, including the measurement of the noise generated by the production process. Meanwhile, if this noise is exposed to workers for a long period of time, it can cause health problems in workers, especially on hearing aids.

The noise level according to the law has a predetermined threshold value. The threshold for noise in industrial environments is known to be $85 \mathrm{~dB}$ with an exposure time not exceeding 8 hours of work. Industries that have carried out noise measurements and the results are higher than the threshold value are required to carry out noise monitoring.

Noise with a noise level lower than $85 \mathrm{~dB}$ if exposed to workers in less than 8 hours is less likely to cause hearing loss. On the other hand, high- 
intensity noise levels exposed to workers in less than 8 hours can lead to claims of hearing loss until they experience advanced hearing loss (Busyairi, Tosungku and Patibong, 2014).

Noise-induced hearing loss takes place slowly, over a few months or years. It is often unnoticed by the person who is suffering, so by the time the person begins to complain about a hearing loss, it is generally already in an irreversible stage. In this case, it is influenced by the working time or duration of the worker's work at the workplace (Ibrahim, Basri and Hamzah, 2016).

Respondents who work long hours are exposed to a high risk of hearing complaints as they are too close to the noise source. Working time that is not in accordance with the standards also causes high noise exposure that can cause hearing loss, supported by the presence of workers who do not follow the regulation in the use of personal protective equipment in the company (Azzahri and Indriani, 2019).

Other factors that can affect the development of hearing loss are the age and use of personal protective equipment in the form of ear plugs. Age can affect the onset of hearing loss because the older a person is, the lower the function of the hearing organs, so someone who works in a noisy place will be at greater risk of hearing loss. A person working in a noisy place at a young age can also potentially suffer from hearing loss. This can occur through support for other activities conducted outside of work in a noisy environment. For example, in a young person who in his daily activities has the habit of listening to music using earphones at a loud volume and with frequent intensity, it can also affect his hearing function.

In some studies, this age has no effect on hearing loss. Based on some research, age can affect the occurrence of hearing loss due to several factors not only because of working in a noisy environment, but also because of habits that are carried out after work and during work Older people or youths are at risk of hearing loss but are influenced by external factors.

Several studies related to the use of personal protective equipment state that PPE may help decrease hearing loss in workers. Companies, therefore, should provide personal protective equipment for workers, but if workers are not obedient in using them when working, it can also cause a high number of occupational diseases, namely hearing loss.
The use of personal protective equipment provided by the company is sometimes still regarded as trivial by some workers. There are three underlying reasons that individuals do not comply with the use of personal protective equipment, namely behaviour, supervision and knowledge. Two strategies that can be effectively implemented are company supervision related to the use of personal protective equipment. Moreover, the company may reward workers who are obedient in spite of being under supervision. This method works because workers will want to be rewarded for using personal protective equipment docilely during work (Candra, 2015).

\section{CONCLUSION}

Based on the outcomes of the study, it is found that the factors that influence the occurrence of hearing loss are individual characteristics such as age, years of service, use of personal protective equipment and noise intensity. Other components that influence hearing loss are length of service, drug use, headset use, smoking, alcohol consumption, history of hypertension, history of diabetes mellitus, and history of hypercholesterolemia. This is known from the outcomes of the analysis conducted throughout the study, but these other factors do not directly affect the occurrence of hearing loss.

\section{ACKNOWLEDGEMENTS}

I would like to send deep gratitude (Alhamdulillah) to God for giving me His blessing so that I was able to complete this study on literature review. Also, I would like to say thank you to the authors of the journals which were used as a reference for the work of this literature review. Writing a journal with literature review method is not easy as it requires detailed stages to know the similarities and differences in each journal until the research questions can be resolved properly. Hopefully this literature review can be a source of literature to guide further research on this topic.

\section{REFERENCES}

Azzahri, L. M. and Indriani, R. I. (2019) 'FaktorFaktor yang Berhubungan dengan Keluhan Pendengaran pada Pekerja Dibagian Produksi di PT. Hervenia Kampar Lestari', PREPOTIF: Jurnal Kesehatan Masyarakat, 3(2), pp. 9-22. 
Buksh, N. et al. (2018) 'Worker' S Health and Activities', International Journal of Public Health and Clinical Sciences, 5(2), pp. 180-195.

Busyairi, M., Tosungku, L. O. A. S. and Patibong, A. (2014) 'Pengaruh Kebisingan Pembangkit Listrik Tenaga Diesel terhadap Keluhan Gangguan Pendengaran Karyawan (Studi Kasus : PT. PLN (Persero) Wilayah Kaltim Sektor Mahakam PLTD X Samarinda)', in Seminar Nasional IENACO ISSN : 2337 - 4349, pp. 12-20.

Candra, A. (2015) 'Hubungan Faktor Pembentuk Perilaku Dengan Kepatuhan Penggunaan Alat Pelindung Telinga Pada Tenaga Kerja Di PLTD Ampenan', The Indonesian Journal of Occupational Safety and Health, 4(1), pp. 83-92.

Chusna, N. A., Huboyo, H. S. and Andarani, P. (2017) 'Analisis Kebisingan Peralatan Pabrik terhadap Daya Pendengaran Pekerja di PT Pura Barutama Unit Pm 569 Kudus', Teknik Lingkungan, 6(1), pp. 1-10.

Fachrul, M. F., Moerdjoko, S. and Verogetta, L. (2016) 'Pengukuran Tingkat Kebisingan terhadap Gangguan Kesehatan Pekerja di Pabrik IB PT Pupuk Sriwidjaja Palembang', Indonesian Journal of Urban and Environmental Technology, 7(1), pp. 1-6.

Hidayat, Purnawati, K. and Dahliyani M, A. S. (2019) 'Faktor Risiko Gangguan Pendengaran pada Pekerja di Bagian Produksi PT Semen Tonasa Kab Pangkep', Jurnal Sulolipu : Media Komunikasi Sivitas Akademika dan Masyarakat, 19(2), pp. 187-197.

Ibrahim, H., Basri, S. and Hamzah, Z. (2016) 'Faktor-faktor yang Berhubungan Dengan keluhan Gangguan Pendengaran Pada Tenaga Kerja Bagian produksi PT. Japfa Comfeed Indonesia, Tbk. Unit Makassar Tahun 2014', Al-Sihah : Public Health Science Journal, 8(2), pp. 121-134.

Jayanti, S., Suwondo, A. and Marlina, S. (2016) 'Analisis Faktor Risiko Gangguan Pendengaran Sensorineural pada Pekerja PT X Semarang', Jurnal Kesehatan Masyarakat (e-Journal), 4(1), pp. 359-366.

Kusmindari, C. D. (2008) 'Pengaruh Intensitas Kebisingan Pada Proses Sugu dan Proses Ampelas Terhadap Pendengaran Tenaga Kerja di Bengkel Kayu X', Jurnal Ilmiah TEKNO, 05(02), pp. 87-96.
Marisdayana, R., Suhartono and Nurjazuli (2016) 'Hubungan Intensitas Paparan Bising Dan Masa Kerja Dengan Gangguan Pendengaran Pada Karyawan PT. X', Jurnal Kesehatan Lingkungan Indonesia, 15(1), pp. 22-27.

Minggarsari, H. D. and Sahuri (2019) 'Hubungan Intensitas Kebisingan dengan Keluhan Auditori pada Pekerja Bagian Produksi Pabrik Fabrikasi Baja', Binawan Student Journal (BSJ), 1(3), pp. 137-141.

Mulyati, S., Jubaidi and Ali, H. (2015) 'Faktor-Faktor yang Berhubungan dengan Gangguan Pedengaran pada Tenaga Kerja PT BNT Bengkulu Tengah', Jurnal Media Kesehatan, 8(1), pp. 51-56.

Ramadhani, P. N. and Firdausiana, Y. D. (2020) 'Paparan Kebisingan dan Gangguan Pendengaran pada Operator Lapangan Area Compressor House', Jurnal Kesehatan Lingkungan, 12(2), pp. 126-135.

Retnaningsih, R. (2016) 'Hubungan Pengetahuan Dan Sikap Tentang Alat Pelindung Telinga Dengan Penggunaannya Pada Pekerja Di PT. X', Journal of Industrial Hygiene and Occupational Health, 1(1), p. 67.

Royan, R. F., Dermawan, D. and Wiediartini (2015) 'Studi Analisis Pengaruh Kebisingan dan Karakteristik Pekerja Terhadap Gangguan Pendengaran Pekerja di Bagian Produksi ( Studi Kasus: PT . Industri Kemasan Semen Gresik, Tuban Jawa Timur )', in Proceeding 1st Conference on Safety Engineering and Its Application, pp. 156-160.

Sincihu, Y.et al. (2019) 'Investigation of Noise Induced Hearing Loss at Shipyard Company, Surabaya', The Indonesian Journal of Occupational Safety and Health, 8(3), pp. 325-331.

Suryani, Mulyadi, A. and Afandi, D. (2015) 'Analisis Gangguan Pendengaran Tipe Sensorineural pada Pekerja Akibat Kebisingan di Industri Mebel Kayu di Kota Pekanbaru', Jurnal Ilmu Lingkungan, 9(1), pp. 1-11.

Umyati, A., Yadi, Y. H. and Anton (2015) 'Pengaruh Tingkat Kebisingan terhadap Gangguan Pendengaran pada Karyawan PT. Citratama Persada Raya Sektor Blasting Painting, in IENACO 2015, pp. 155-162. 